\title{
DUKUNGAN SUAMI DENGAN PEMILIHAN KOTRASEPSI IUD PADA PASANGAN USIA SUBUR
}

\author{
Sefrina Rukmawati ${ }^{1}$, Luthfi Sholichul Ardian², Puji Astutik ${ }^{3}$ \\ ${ }^{123}$ STIKes Satria Bhakti Nganjuk \\ Email : sefrinarkmawati99@gmail.com
}

\begin{abstract}
Introduction : Contraception is part of reproductive health services for the regulation of pregnancy, and is the right of every individual as a sexual being. There are two methods of contraception that are Non-MKJP (Non Long Term Contraception Method and MKJP (Long Term Contraception Method) one of them is IUD Contraception IUD is a contraceptive device installed in uterus which is relatively more effective than other contraception. knowing the relationship of husband support with IUD contra ception election at Pria Age Subur (PUS) in Jatirejo Village Nganjuk regency. Methods: This research use correlation research method with cross sectional, conducted on February 21, 2018. Population in this research is All acceptor of new KB in January-August as many as 38 people. Sampling used total sampling. Independent variable of research is husband support, while research dependent variable is IUD contraception choice. Data collection with questionnaires. Data analysis with Coefficient Contingency test with $\alpha=0,05$. Results: The result of the research shows that most of respondents $(55,3 \%)$ have good support from husband while most of them are 21 respondents $(55,3 \%)$ respondents in IUD contraception choice have good husband support. Coefficient Contingency test results show $\rho$ value $=0,000 \leq \alpha=0,05$ and so Ho is rejected and Ha accepted. Conclusions: There is a relationship of husband support with the selection of iUD cotration on the couples of childbearing age (pus) in Jatirejo village Nganjuk regency so it is necessary counseling on husband about the importance of husband support in choosing the most appropriate contraception.
\end{abstract}

\section{Keywords: Husband Support, Constitueption Selection, IUD Contraception, EFA}

PENDAHULUAN

Kontrasepsi merupakan bagian dari pelayanan kesehatan reproduksi untuk pengaturan kehamilan, dan merupakan hak setiap individu sebagai makhluk seksual (BKKBN, 2011). Metode kontrasepsi dibagi menjadi 2 yaitu Non-MKJP (Bukan Metode Kontrasepsi jangka Panjang) dan MKJP (Metode Kontrasepsi Jangka Panjang) salah satunya yaitu IUD , (Departemen Kesehatan RI, 2008). IUD merupakan alat kontrasepsi yang dipasang dalam rahim yang relatif lebih efektif bila dibandingkan dengan metode pil, suntik, dan kondom (Setiayaningrum, 2015). Dalam penggunaan kontrasepsi, ada beberapa faktor yang mempengaruhi dalam pemilihan salah satunya faktor eksternal yang berupa dukungan suami misalnya suami mengantar dan membiayai istri untuk memasang KB IUD (Pendit, 2006). Sebagai kepala rumah tangga 
pendapat suami mengenai $\mathrm{KB}$ cukup berpengaruh untuk menentukan pemilihan kontrasepsi (Angaraini, 2007).

Dimana sebanyak $59,3 \%$ mengunakan kontrasepsi moderen, dan hanya $0,4 \%$ yang menggunakan kontrasepsi cara tradisional. Selain itu dapat di ketahui pula bahwa sebanyak $24,8 \%$, dari pasangan usia subur mengaku pernah menggunakan kontrasepsi, meski saat ini tidak menggunakanya. Sedangkan 15,5\% pasangan usia subur mengaku tidak pernah menggunakan kontrasepsi, (Riskesdes,2013).

Menurut Jasmaniar (2013) minat penggunaan kontrasepsi dipengaruhi oleh pengetahuan, pendidikan, usia, dan dukungan suami. Pada penelitian Marliani (2011), minat yang timbul dalam hati seorang istri bisa disebabkan karena adanya dorongan dan dukungan dari luar seperti dari suami atau keluarga. Dukungan suami biasanya berupa perhatian dan memberikan rasa nyaman serta percaya diri dalam mengambil keputusan tersebut dalam pemilihan alat kontrasepsi. Kurangnya dukungan suami yang diberikan akan mempengaruhi minat dan kepercayaan diri istri untuk memilih kontrasepsi yang ingin digunakan.

Peran suami dalam Keluarga Berencana antara lain sebagai peserta
Keluarga Berencana dan mendukung pasangan menggunakan alat kontrasepsi. Upaya untuk meningkatkan partisipasi suami dalam program Keluarga Berencana adalah dengan meningkatkan dukungan suami dalam pemilihan kontrasepsi sehingga suami dapat ikut serta menemani istrinya menemui konselor keluarga berencana atau petugas kesehatan untuk mengetahui metode kontrasepsi yang tersedia dan memilih salah satu metode kontrasepsi yang tepat, dan memperhatikan tanda-tanda bahaya pemakaian kontrasepsi terutama kontrasepsi IUD. Dukungannya dapat berupa informasi atau nasehat verbal dan non verbal, bantuan nyata atau tindakan yang diberikan oleh keakraban sosial atau didapat karena kehadiran suami dan mempunyai manfaat emosional atau efek perilaku bagi pihak penerima (istri) (Ninuk, 2007).

Dukungan suami merupakan salah satu faktor penguat yang dapat mempengaruhi seseorang dalam berperilaku. Sedangkan dukungan suami dalam KB merupakan bentuk nyata dari kepedulian dan tanggung jawab para pria. Aspek-aspek yaitu dukungan emosional, informasi, instrumental dan penghargaan (Friedman,2010).

Hasil wawancara didapatkan sebanyak 15 orang istri, 3 orang istri 
menggunakan kontrasepsi suntik, 5 orang istri menggunakan kontrasepsi implan, dan 7 orang istri menggunakan kontrasepsi IUD. Dari 15 orang istri yang menggunakan kontrasepsi, 10 di antaranya bermusyawarah sebelum mengambil keputusan, sedangkan 5 orng istri dalam pengambil keputusan sendiri tanpa didasari musyawarah sebelumnya. Atas dasar permasalahan tersebut maka peneliti ingin meneliti tentang dukungan suami dengan pemilihan kontrasepsi IUD pada pasangan usia subur (PUS) di kelurahan Jatirejo Kabupaten Nganjuk.

\section{METODE}

Desain penelitian menggunakan korelasi dengan pendekatan secara cross sectional karena pengambilan data variabel independen dan variabel dependen dilakukan hanya satu kali pada satu saat. Jadi tidak ada tindak lanjut (Nursalam, 2016). Penelitian dilaksanakan pada tanggal 21 Februari 2018 di wilayah Kelurahan Jatirejo Kecamatan Nganjuk Kabpuaten Nganjuk. Populasi pada penelitian ini didapatkan sebanyak 38 orang pada bulan Januari-Agustus 2017. Dan tehnik sampling yang digunakan adalah teknik total sampling. Total sampling yaitu teknik pengambilan sempel dimana jumlah sempel sama dengan populasi (Sugiono, 2007). Alasan mengambil total sampling karena menurut Sugiono (2007) jumlah populasi yang kurang dari 100 seluruh populasi di jadikan sample penelitian semuanya. Sehingga sample yang diambil dalam penelitian ini sebanyak 38 responden. Variabel independen pada penelitian ini adalah dukungan suami yang diukur menggunakan kuesioner dukungan suami dan pemilihan kontrasepsi IUD. Teknik analisis untuk uji hipotesis menggunakan uji statistik Coefisient Contingency dengan tingkat signifikan $\alpha=0,05$

\section{HASIL}

Tabel 1 Distribusi Frekuensi Dukungan Suami dan Pemilihan IUD di wilayah Kelurahan Jatirejo Kecamatan Nganjuk Kabupaten Nganjuk

\begin{tabular}{clcc}
\hline No & Dukungan Suami & $\sum$ & \% \\
\hline 1 & Baik & 21 & 55,3 \\
2 & Cukup & 12 & 31,6 \\
3 & Kurang & 5 & 13,2 \\
\hline \multirow{2}{*}{ Total } & Pemilihani IUD & $\sum$ & $\mathbf{3 8}$ \\
\hline 1 & IUD & 21 & 55,3 \\
2 & Non IUD & 17 & 44,7 \\
\hline & Total & $\mathbf{3 8}$ & $\mathbf{1 0 0}$ \\
\hline
\end{tabular}

Tabel 2 Tabulasi silang hubungan dukungan suami dengan pemilihan kontrasepsi IUD pada pasangan usia suabur (PUS) di kelurahan Jatirejo kabupaten Nganjuk 


\begin{tabular}{|c|c|c|c|c|c|c|}
\hline \multirow{3}{*}{$\begin{array}{l}\text { Dukungan } \\
\text { suami }\end{array}$} & \multicolumn{4}{|c|}{ kontrasepsi } & & \\
\hline & \multicolumn{2}{|c|}{ IUD } & \multicolumn{2}{|c|}{ Non IUD } & \multicolumn{2}{|c|}{ Total } \\
\hline & $\Sigma$ & $\%$ & $\Sigma$ & $\%$ & $\Sigma$ & $\%$ \\
\hline Baik & 18 & 85,7 & 3 & 17,6 & 21 & 55,3 \\
\hline Cukup & 3 & 17,6 & 9 & 42,9 & 12 & 31,6 \\
\hline Kurang & 0 & 0 & 5 & 29,4 & 5 & 13,2 \\
\hline Total & 21 & 100 & 17 & 100 & 38 & 100 \\
\hline \multicolumn{7}{|c|}{$\begin{array}{l}\text { Uji Contigency Coefisient didapatkan } \rho \text { value }= \\
\qquad 0,000 \leq \alpha=0,05\end{array}$} \\
\hline
\end{tabular}

Berdasarkan tabel 2 : Dapat

diketahui bahwa dari sebagian besar yaitu 21 responden $(55,3 \%)$ memiliki dukungan yang baik dan berdasarkan uji Coefficien Contingency didapatkan $p$ value: 0,000, karena $\rho$ value $0,000 \leq \alpha(0,05)$ sehingga Ho di tolak dan H1 di terima yang berarti ada hubungan dukungan suami dengan pemilihan kontrasespi IUD di wilayah kelurahan Kabupaten Nganjuk.

\section{PEMBAHASAN}

\section{Dukungan suami Pada Pasangan Usia}

\section{Subur (PUS)}

Hasil analisa data didapatkan bahwa dari 38 responden, sebagian besar 21 responden $(55,3 \%)$ memiliki dukungan baik dari suaminya. Dari hasil uji statistik di dapatkan $\rho$-value pekerjaan suami $=$ $0,027 \rho$-value pendidikan suami $=0,009$. Maka dukungan suami di pengaruhi oleh faktor pekerjaan dan pendidikan suami.

Setiadi (2008) bahwa dukungan suami merupakan sifat interaksi yang berlangsung dalam berbagai hubungan sosial sebagaimana yang dievaluasi individu, yaitu istri. Pada dasarnya, dukungan suami mengacu kepada dukungan sosial keluarga yang berasal dari suami ayah, ibu maupun dari mertua. Faktor yang mempengaruhi dalam penggunaan kontrasepsi salah satunya adalah dukungan sosial khususnya dari suami, pasangan harus saling mendukung satu sama lain termasuk juga penggunaan alat kontrasepsi (Gebremariam, 2014). Faktor pekerjaan juga akan berpengaruh pada penggunaan kontrasepsi pada ibu, hal ini didukung dalam artikel penelitian menyebutkan bahwa pekerjaan mempunyai hubungan signifikan terhadap penggunaan kontrasepsi jangka panjang (Sahilemichaelet al, 2015).

\section{Pemilihan kontrsepsi IUD Pada Pasangan Usia Subur (PUS)}

Dari analisa data didapatkan dari 38 responden, sebagian besar yaitu 21 responden $(55,3 \%)$ memilih kontrasepsi IUD.

Tindakan seseorang dalam pemilihan kontrasepsi IUD dipengaruhi oleh faktor predisposisi salah satunya adalah pengetahuan. . Pengetahuan bisa di peroleh dari media cetak ataupun media masa lainnya tingkat pendidikan seseorang berpengaruh dalam memberikan responterhadap sesuatu yang datang dari luar. Seseorang yang mempunyai tingkat 
pendidikan tinggi akan memberikan respon yang lebih rasional dari pad berpendidikan rendah, (Notoatmodjo, 2003).

Hasil penelitian tidak sejalan dengan penelitian yang dilakukan Kusumaningrum (2009) yang menyatakan bahwa tidak ada hubungan antara jumlah anak (paritas) dengan penggunaan IUD. Hasil penelitian menunjukkan bahwa ibu yang memiliki lebih 2 anak cenderung tidak memilih IUD dengan berbagai alasan, salah satunya adalah alasan responden atau ibu merasa kurang nyaman dan merasa ketakutan dengan proses pemasangan IUD.

Pemilihan Kontrasepsi pada pasangan usia subur di pengaruhi oleh faktor pendidikan. Seseorang yang mempunyai pendidikan tinggi akan memeberikan respon yang lebih rasional dari pada berpendidikan lebih rendah. Responden yang pendidikan lebih tinggi mempunyai pengetahuan baik terkait alat kontrasepsi IUD sehingga mereka akan lebih memilih kontrasepsi IUD dari pada metode yang lain. Sedangkan terkait jumlah anak Ibu yang memiliki 2 anak atau lebih dianjurkan untuk menggunakan alat kontrasepsi jangka panjang seperti IUD karena memiliki efektifitas yang tinggi dari pada metode kontrasepsi yang lainnya. Namun kurangnya informasi sehingga mereka lebih cenderung mengalami ketakutan atau kekhawatiran ketika menggunakan kontrasepsi IUD.

Hubungan dukungan suami dengan pemilihan kotrasepsi IUD Pada

\section{Pasangan Usia Subur (PUS)}

Hasil analisa data didapatkan bahwa dari 38 responden, hampir seluruhnya $(85,7 \%)$ memiliki dukungan suami yang baik dengan pemilihan kontrapsepsi IUD. Berdasarkan hasil uji Coeficient Contingency menunjukkan $\rho$ value $0,000 \leq \alpha 0,05$. Sehingga dapat disimpulkan $\mathrm{Ha}$ diterima artinya ada hubungan dukungan suami dengan pemilihan kontrasepsi IUD pada pasangan usia subur.

Dukungan dapat berupa informasi atau nasehat verbal dan non verbal, bantuan nyata atau tindakan yang diberikan oleh keakraban soaial atau didapat karena kehadiran suami dan mempunyai manfaat emosional atau efek perilaku bagi pihak penerima (istri) (Kurniawati,2007). Notoatmodjo (2003) menyatakan bahwa suami merupakan salah satu unsur pendukung dlam perilaku sesorang. Dukungan suami mempunyai andil yang besar bagi tindakan seseorang istri untuk memilih kontrasepsi yang akan dipakainya. Hal ini sejalan dengan Penelitian Isti (2007), faktor yang mempengaruhi dukungan suami salah 
satunya yairu tingkat pengetahuan, dimana semakin baik ingkat pengetahuan suami tentang alat kontrasepsi maka semakin baik pula dukungan yang diberikan suami dalam pemilihan alat kontrasepsi.

Nuryati \& Fitria (2014), juga mengungkapkan ada hubungan yang bermakna antara dukungan suami dengan pemilihan alat kontrasepsi. Sehingga, dapat disimpulkan bahwa semakin tinggi dukungan dari suami. maka semakin tinggi pula prosentase penggunaan alat kontrasepsi yang sesuai dengan karakteristik dan kebutuhan istri. Salah satu faktor penguat yang yang mempengaruhi pemilihan kontrasepsi diantaranya dukungan suami. Peran suami sebagai kepala keluarga merupakan faktor penentu dalam pemilihan kontrasepsi. Komunikasi efektif yang terjalin bagi suami dan istri memberikan dampak positif terutama dalam pemasangan dan kontrol KB.

\section{KESIMPULAN}

Dukungan suami di Kelurahan Jatirejo Kabupaten Nganjuk, sebagian besar dalam kategori baik yaitu 21 responden $(55,3 \%)$. Suami diharapkan berperan aktif dalam mendukung istri untuk melilih kontrasepsi yang tepat .Pemilihan kotrasepsi IUD di kelurahan jatirejo kabupaten nganjuk 21 sebagian besar responden (55,3\%). Pasangan usia subur diharapkan memilih kontrasepsi IUD dan mencari informasi tentang pemasangan maupun efek samping yang diberikan. Terdapat hubungan dukungan suami dengan pemilihan kotrasepsi IUD pada pasangan usia subur (PUS) di Kelurahan Jatirejo Kabupaten Nganjuk. Hal ini ditujukkan hasil uji Coeficient Contingency dsidapatkan $\rho$-value $0,000 \leq$ $\alpha 0,05$. sehingga itu Alat kontrasepsi IUD merupakan alat kontrasepsi yang dipasang dalam rahim yang relatif lebih efektif sehingga perlunya dukungan suami dalam pemeilihan kontrasepsi yang paling tepat untuk istri sehingga sumi istri mersa nyaman.

\section{DAFTAR PUSTAKA}

Afandi, B. (2011). Buku Panduan Praktik Pelayanan Kontraspsi. Jakarta: BKKBN.

Angraini, M.D .(2007). Peran Suami Dalam Penggunaan Alat Kontrasepsi Yang Berwawasan Gender. Jawa Tengah: Univesitas Jendral Soederman

Anwar, M. Baziad, A (2011). Ilmu kandungan edisi ke tiga. Jakarata:BPSP

Arikunto,S. (2010). Prosedur Penelitian Suatu Pendekatan Praktik. Jakarta: Rineka Cipta.

Astutik, R.Y. (2014). Buku Ajar Keperawatan dan Laktasi edisi ke 4. Jakarta: Salemba Medika

Bobak, dkk. (2004). Buku Ajar keperawatan Maternitas. Edisi 4. Jakarta: EGC

Departemen Kesehatan RI. (2008).Buku panduan praktis pelayanan kontrasepsi. Jakarta: Yayasan Bina Pustaka 
Friedman,\& Marlyn, M.(2010). Buku ajar kePerawatan keluarga:riset, teori \& praktek. Jakarta: buku kedokteran EGC.

Gebremariam A, Addissie A. (2014). Intention to use long acting and permanent contraceptive methods and factors affecting it among married women in Adigrat town, Tigray, Northern Ethiopia. Reproductive Health. 11(1): $24 . \quad$ doi: http://dx.doi.org/10.1186/1742- 475511-24 di akses pada tanggal 20 Juni 2018

Hartanto, H. (2004). Keluarga berencana dan kontrasepsi.jakarta:CV MLIA SARI

Hidayat, A. (2007). Pengantar Ilmu keperawatan Anak jilid 1. Jakarta : Salemba Medika.

Irianto, K. (2014) Pelaynan Keluaraga Berencana Duana Cukup. Bandung: ALAFABETA

Jasmaniar. (2013). Faktor-Faktor Yang Mempengaruhi Minat Akseptor KB Terhadap Pemakaian Alat Kontrasepsi Impant Di Puskesmas Simeulue Timur. Skripsi. STIKes U'Budiyah Banda Aceh.

Marlaini.(2011).Gambaran Faktor-Faktor Yang Berhubungan Dengan Minat Ibu Menggunakan Kontrasepsi Implant DiPuskesmas Mesjid Raya KecamatanMesjid Raya Kabupaten Aceh Besar. KTI STIKes U'Budiyah Banda Aceh.

Muchtar,W.(2000). Pedoman

Penggarapan Peningkatan Partisipasi Pria Dalam Program KB \& Kesehatam Reproduksi Yang Berwawasan Jemder,jakarta .BKKBN

Muhammad,. (2009). Teknik kip/pelayan kontrasepsi. Jawa timur.bkkbn

Nursalam.(2016). Metodologi Penelitian Ilmu Keperawatan: Pendekatan Praktik. Jakarta: Salemba Medika.

Notoatmodjo, S. (2010). Metode Penelitian Kesehatan. Jakarta:RinekaCipta.
Pendit, B.U. (2006). Ragam metode kontrasepsi. Jakarta : EGC

Purwoastuti, E (2015).Ilmi Kesehatan Masyarakat Dalam Kebidanan nsep, Teori, Dan Aplikasi.Yogyakarta:PB

Sahilemichael A (2015). Determinants of Long Acting Reversible Contraceptives Use among Child Bearing Age Women in Dendi District, Western Ethiopia. Journal of Womens Health Care, 4(4). doi: $\quad 10.4172 / 2167-0420 .-1000242$ diakses pada tanggal 20 juni 2018

Setiadi. (2008) . Konsep dan Proses Keperawatan Keluarga. Surabaya : Graha Ilmu.

Setiadi. (2013). Konsep dan Praktik Penulisan Riset Keperawatan. Yogyakarta: Graha Ilmu

Setiani, N. Dhevita,(2016). Keseahatn Reproduksi Untuk SMK kesehatan. Jakarta : EGC

Setiyaningru, E.(2015). Pelayan Keluarga Berencana \& Kesehatan Reproduksi Edisi Revis. Jakarta:TIM

Saifuddin. 2006. Buku PedomanPraktis PelayananKontrasepsi. Jakarta Yayasan Bina Pustaka.

Syaifuddin, M. (2013). Dukungan Suami dengan Tindakan Istri dalam Pemilihan Kontrasepsi Suntik Di Desa Warujayeng Kecamatan Tanjunganom Kabupaten Nganjuk. Skripsi. Nganjuk : STIKes Satria Bhakti Nganjuk.

Thahjadi.(2008).Panduan Peningkatan Partisispasi Pria DalamKB ,jakarta. BKKBN

WHO. (2014). Penggunaan Kontrasepsi. [Internet] Bersumber dari: https:/www.google.co.id/url?sa=\&so urce $=$ j\&url $=$ http://eprits.ums.ac.id $/ 33$ 7661/4/BAB[Diakses tanggal 13 September 2017].

Yuhedi, L.Titik (2015).buku ajar kependudukan \& pelayanan KB.Jakarta:EGC 